\title{
Biomechanical Evaluation of the Neck and Shoulder When Using Pillows with Various Inner Materials
}

\author{
Jung Yong Kim, Ji Soo Park ${ }^{1}$, Dae Eun Park² \\ ${ }^{1}$ Department of Industrial and Management Engineering, Hanyang University, Ansan, 426-791 \\ ${ }^{2}$ Consulting Team, Department of Safety and Technology, Korea Industrial Safety Association, Seoul, 152-838
}

\begin{abstract}
Objective: The purpose of this study was to evaluate of various material of pillows by using biomechanical variables such as the cervical stability, head pressure distribution, and muscle activity. Method: Eight subjects participated in the experiment. Three different materials such as polyester sponge, memory foam and the buckwheat shell used for Korean traditional pillow were tested. Electro-goniometer, six channels of electromyography(EMG), ten channels of the head pressure sensors were used to measure the biomechanical responses. Surface electrodes were attached to the right/left semispinals capitis(RSC, LSC), the right/left sternocleidomastoid(RSM, LSM), the right/left upper trapezius(RUT, LUT). The cervical stability was evaluated by the angle deviated from the standing neck position. The head pressure distribution was evaluated by the pressure per unit area recorded on the sensors and the intensity of peak pressure. Electromyography(EMG) data were analyzed by using root mean square(RMS) and mean power frequency(MPF). Results: The buckwheat shell material showed a higher stability in the cervical spine then the other pillows during spine position. In terms of head pressure distribution, the memory form indicated the lowest pressure at supine position, buckwheat shell material indicated the lowest pressure during lying down to side, and polyester cushion recorded the highest pressure at all postures. Conclusion: The buckwheat shell material has a biomechanical advantage to maintain a healthy neck angle and reduce the pressure on the head, which means the buckwheat shell is a potential material for ergonomic pillow design. The pillow with memory form showed second best biomechanical performance in this study. Application: The shape of the buckwheat shell pillow and the characteristics of materials can be used to design the pillow preventing neck pain and cervical disk problems.
\end{abstract}

Keywords: Buckwheat shell pillow, Cervical stability, EMG, Head surface pressure

\section{Introduction}

인간에게 수면은 심신의 피로를 회복하고 건강을 유지하 기 위하여, 낮 동안의 신체적, 정신적 피로를 회복시키는 작용을 한다. 또한 우리 몸의 대사기능의 균형을 회복시켜주 고 누적된 근육의 피로를 풀어주며, 신경세포의 재합성을 도 와주는 역할도 담당하고 있다. 따라서 충분한 질과 양의 수 면을 취하기 위해서는 숙면할 수 있는 환경이 필요하다. 숙
면을 취하기 위한 환경으로 대표적인 것이 침구이며, 우리나 라의 경우 베개, 이불, 요 등을 기본적인 침구로 사용하고 있 다. 이중 베개는 누운 자세에서 신체를 자연 그대로의 상태 로 지지해주고 바닥으로부터 전해오는 소리나 진동을 차단 해 주고 두부(頭部)를 편안하게 쉬게 해주는 역할을 함으로 서 수면에 큰 영향을 준다. 부적합한 베개를 계속 사용할 경 우 수면의 장애를 가져오며, 경부근육의 통증을 일으키기도 하며, 만성피로의 원인이 되기도 한다.

베개가 편안한 수면을 제공해 주는 것은 크기, 높이, 촉감, 
흡수성, 속재료의 탄성, 열전도성, 형태안정성 등의 복합적인 작용에 의한다고 한다(Nam and Lee, 1989). 특히, 목 부위 의 자세에 의하여 수면을 취하는 동안 경부통증이 악화되기 도 한다고 Cyriax(1988) 와 Liebenson(1996)의 연구에서 보고하고 있다. 경부통증이 수면 동안의 잘못된 자세로 인하 여 악화될 수 있다고 주장하고, 이상적 수면 자세의 조건을 제시하였는데 이상적 자세는 정상적인 척추만곡이 유지되며 근육긴장이 없는 자세로, 바로 누운 자세에서는 정상적인 경 추의 만곡이 유지되고, 옆으로 누운 자세에서는 경추와 흉추 가 일직선이 되어 근육긴장이 없고 후관절(facet joint)에 무 리가 가해지지 않아야 한다고 하였다. Kwon et al.(1998)은 40명의 정상인의 수면 자세를 관찰한 후 베개를 디자인하였 다. 디자인한 베개를 경부통증환자를 대상으로 사용하게 한 후 통증의 경감 정도, 수면의 질, 베개의 만족도 등을 비교하 였다. 그 결과 머리와 경부의 자세 및 모양에 따라 디자인된 베개가 경추의 정상적 만곡유도 및 경부를 충분히 지지할 수 있었고, 모양에 따른 성형효과 및 재질로 인한 머리무게를 분산시키며, 형태적 특성상 수면시 과도한 경부의 움직임을 방지하는 효과로 인하여 수면의 질 및 베개의 만족도를 향상 시킨다고 하였다.

편안한 수면 자세를 유지하기 위한 베개 연구로 Robert et al. (1997)이 표준 베개와 물 베개 (water-based pillow) 의 차이에 대하여 주관적 설문을 이용하여 조사였다. 물 베 개가 머리의 무게를 분산시킬 수 있다고 하였으나, 물 베개 는 경추의 정상적인 만곡 및 수면 자세와는 관계없이 단순 히 물의 부력을 이용 머리무게를 분산한다는 단점을 가지고 있는 것으로 나타났다.

Cyriax(1988)와 Liebenson(1996)은 이상적인 베개의 조건은 척추의 정상적인 정렬을 유지하면서 목 부위를 지지 해야 한다고 하였고, 어깨 넓이에 따라 베개의 크기도 조정 되어야 경부와 머리가 동시에 지지된다고 하였다.

Nam and Lee(1989)는 베개의 높이에 대하여 근전도와 $\mathrm{x}$-선을 이용하여 평가하였다. 남자는 바로 누운 자세에서 $8.0 \pm 0.5 \mathrm{~cm}$, 옆으로 누운 자세에서 $9.0 \pm 0.5 \mathrm{~cm}$, 여자는 바 로 누운 자세에서 $6.0 \pm 0.5 \mathrm{~cm}$, 옆으로 누운 자세에서 $8.0 \pm$ $0.5 \mathrm{~cm}$ 가 적절하다고 하였다. Hur and Yang (2006)은 몇 종류의 베개를 실험참가자들이 사용해 보도록 하고, 자세와 만족도, 감성평가, 수면질 등의 평가를 실시하였다. 베개의 형태와 수면 자세에 따라 목 부위의 통증이 차이가 나며 수 면질에도 차이가 있다고 하였다. 하지만, 베개의 경도와 재 질에 대한 고려는 이루어지지 않았다.

편안한 수면 자세에 대한 연구로는 Kwon et al.(1999)이 체압분포를 이용하여 수면 자세를 인식하고 편안한 수면 자세를 도출해내고자 하였다. Kim et al.(2007)은 피부표면 온도와 체압측정기를 이용한 에어볼 매트리스와 일반 매트
리스의 비교 연구하였다. 연구결과 매트리스의 종류에 따라 체압은 크게 차이가 없었지만, 에어볼 매트리스가 피부표면 온도의 증가 속도를 줄여준다고 보고하였다.

자세에 따른 국부근육 피로도에 대한 연구로는 Park and $\operatorname{Kim}(2008)$ 의 앉은 자세에서 어깨 작업 자세에 따른 근육 피로도 변화에 대한 연구가 있다. 이 연구에서는 특정한 어 깨의 정적 작업 자세에서 국부근육이 쉽게 피로해지거나 손 상 받기 쉽다고 하였다. 마찬가지로, 베개와 관련된 수면 자 세도 목과 어깨 부위의 근육에 관련되어 있으므로 자세에 따라 국부근육의 피로도의 차이가 있을 것으로 예상된다.

새로운 베개의 재질이 개발되고 사용됨에 따라, 이러한 베 개에 대한 인체공학적 적합성이 새로운 논의의 주제가 되기 도 한다. 그러므로, 본 연구에서는 메모리폼, 메밀 등의 속재 료가 과연 어떠한 생체역학적 영향을 미치는지 알아보기 위 해 경추 자세의 안정도, 머리 부위와 목의 체압, 복과 어깨 부위의 근육활동도와 국부근육 피로도를 측정하였다. 이러한 다양한 생체역학적 변수를 사용하여 다양한 속재질의 베개 를 평가하는 것이 본 연구의 목적이다. 따라서, 사용자가 생 체역학적으로 편안한 수면 자세를 유지할 수 있는 베게 속 재질 선택하여 사용할 수 있는 정량적 지표를 제시하여 보 고자 하였다.

\section{Method}

\subsection{Participants}

본 연구에서는 목이나 허리에 관련된 근골격계 질환의 병 력이 없고, 현재 건강상태가 양호한 남자 대학원생 8명이 실험에 참여하였다. 실험참가자들의 인체 측정치는 Table 1 과 같다.

Table 1. Anthropometry of participants

\begin{tabular}{c|c|c}
\hline & Mean & S.D. \\
\hline Age(year) & 26.5 & 1.1 \\
\hline Statue $(\mathrm{cm})$ & 178.1 & 4.2 \\
\hline Weight $(\mathrm{kg})$ & 69.6 & 6.8 \\
\hline
\end{tabular}

\subsection{Experimental condition}

본 연구에서는 베개의 종류와 베개를 베고 누운 자세가 근육에 어떤 영향을 미치는지 연구하기 위하여 2 인자 $3 \times 2$ within-subject design을 계획하였다. 독립변수로는 베개 의 종류(3수준: 폴리에스테르 쿠션 베개, 메모리폼 베개, 메밀 베개) (Table 2) 와 자세 (2수준: 바로 누운 자세, 옆으로 
누운 자세)를 선정하였다. 경추의 정상적인 만곡(cervical curvature)을 유지하기 위하여 엎드려 누운 자세는 실험대 상에서 제외하였다. 실험참가자는 두 가지 조건이 조합된 총 6 가지의 실험을 반복하여 실시하였다. 종속변수로는 수면 자 세별 근육의 활동도를 분석하기 위하여 근전도(EMG) 신호 의 RMS (root mean square) 값을 사용하였고, 근육의 피로 도를 분석하기 위하여 근전도 신호의 $\mathrm{MPF}$ (mean power frequency) 값을 사용하였다.

\subsection{Experimental procedure}

실험참가자에게 편안한 복장을 하게 하고 실험목적과 주 의사항을 전달하였다. 실험을 시작하기 전에 실험자에 대한 기본적인 설문을 실시하였다. 설문 후 목 자세 변화 측정에 필요한 기준점(귀구슬점, 어깨가쪽점, 뒤통수점, 목뒤점)을 찾아 표시한 뒤, 6 channels의 표면전극(surface electrode) 을 부착하였다. 자세에 따른 실험순서 및 베개에 따른 실험 순서는 무작위로 실시하였다(Figure 1).

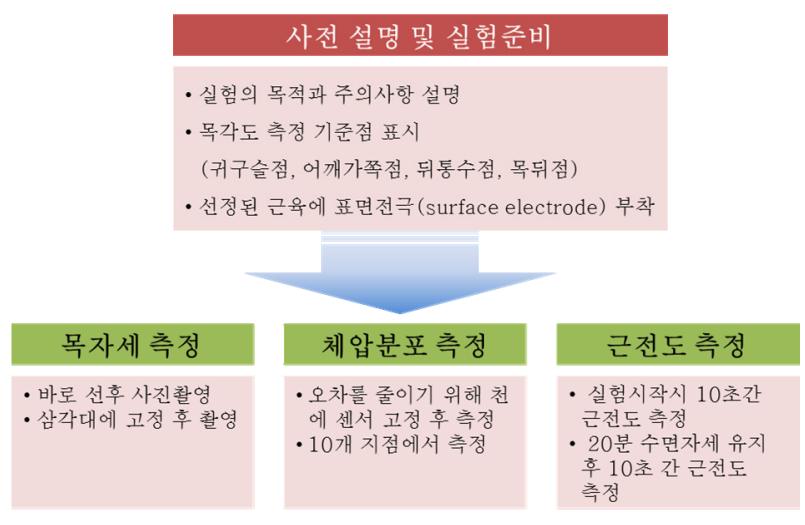

Figure 1. Experimental procedure

\subsubsection{Measurement of neck posture}

목 자세 변화 측정에 필요한 네 곳의 기준점을 표시 후, 실험참가자에게 바로 서도록 하여 사진촬영을 실시하였다. 베개를 베고 누워 가장 편안한 자세를 스스로 찾게 하고, 가 장 편안한 자세를 유지할 때 누워 있는 목 자세를 다시 촬영 하였다. 바로 누운 자세와 옆으로 누운 자세를 번갈아 촬영 하여 표시된 기준점으로 자세의 변화(가상선상의 각도의 변 화)를 전자 관절각도측정기 (electrogoniometer)로 측정하 였다(Figure 2).

목각도 변화량은 Figure 2의 편안하게 선 자세일 때의 목 각도를 기준으로 각 베개를 사용하였을 때의 목각도 변화량 (deviation angle)을 Equation 1, 2를 이용하여 계산하였다.

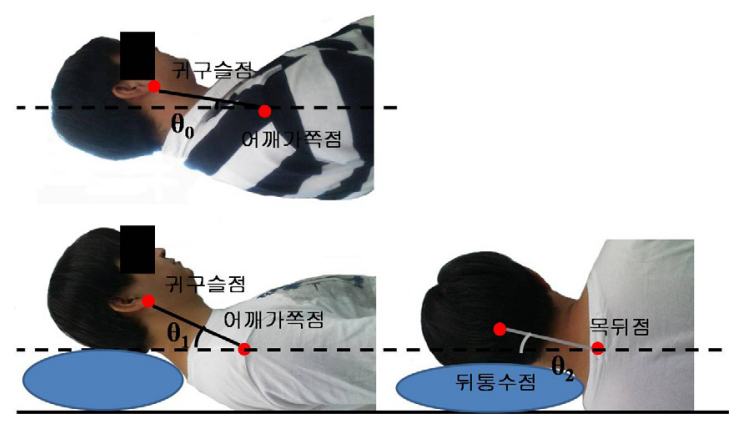

Figure 2. Measurement method of deviated neck angle

목각도 변화량 $($ 바로 누운 자세 $)=\theta_{1}-\theta_{0} \quad \cdots \cdots \cdots$ Equation 1.

목각도 변화량 $($ 옆으로 누운 자세 $)=\theta_{2}$ Equation 2.

위 식에서 $\theta_{0}=$ 선 자세일 때의 목각도

$\theta_{1}=$ 베개를 베고 바로 누운 자세의 목각도

$\theta_{2}=$ 베개를 베고 옆으로 누운 자세의 목각도

\subsubsection{Measurement of pressure}

베개를 베고 누웠을 때 체압이 얼마나 고르게 분포하는지 측정하기 위하여 머리 표면에 가해지는 압력을 측정하였다. 압력 측정점으로는 머리반가시근(semispinals capitis)과 뒤통수점이 만나는 지점 두 곳과 뒤통수점과 뒤통수 돌출 점 사이에 한 곳, 뒤통수 돌출점을 기준으로 평행하게 4곳, 옆머리점과 평행한 가상선을 기준으로 한 두정골 (parietal bone) 부위에 3 곳, 총 10 지점에서 측정하였다. 측정시 오차 를 줄이기 위하여 실험참가자의 머리 표면에 센서를 직접 부착하지 않고 두께를 무시할 수 있는 얇은 천을 사용하여 센서를 고정하여 부착한 후 측정하였다(Figure 4).

\subsubsection{Measurement of electromyography}

실험참가자에게 베개를 베고 눕게 하고 실험참가자 스스 로 베개를 조정하여 가장 편안한 자세를 찾도록 하였다. 실 험시작 시 10 초 간의 근전도를 측정한 후, 실험참가자가 가 장 편안한 자세를 유지한 상태에서 근육활동도와 근육피로 도를 분석하기 위하여 각 자세별로 20 분 동안 베개를 베고 누워 수면 자세를 유지하게 한 뒤 10초 동안의 근전도 신호 를 수집하였다. 실험참가자들의 학습효과를 줄이기 위해 베 개의 순서와 눕는 방법이 무작위 순서가 되도록 하여 신호 를 수집하였다.

\subsection{Apparatus}

베개의 종류가 근육에 어떤 영향을 미치는가를 알아보기 
위하여 3 가지 베개를 실험장비로 선정하였다(Table 2). 폴리 에스테르 쿠션 베개는 $55 \times 33 \times 16 \mathrm{~cm}$ 의 크기의 폴리에스테 르 스폰지(polyester sponge) 재질로 평균 머리무게 $5 \mathrm{~kg}$ 으로 압력을 가했을 때의 높이가 $11 \mathrm{~cm}$ 이었다. 메모리폼 베 개의 경우 $53 \times 30 \times 11$ 의 크기의 압축 스펀지 (compressive sponge) 재질로 그 형태적 특성상 가장 낮은 부분의 높이는 $5.5 \mathrm{~cm}$ 이었으며, 평균 머리무게 $5 \mathrm{~kg}$ 으로 압력을 가했을 때 의 높이가 $9 \mathrm{~cm}$ 이었다. 메밀 베개의 경우 속재질을 메밀껍질 로 만든 $60 \times 40 \times 12 \mathrm{~cm}$ 의 크기의 베개로 그 형태적 특성상 가장 낮은 부분의 높이는 $3 \mathrm{~cm}$ 이었으며, 평균 머리무게 $5 \mathrm{~kg}$ 으로 압력을 가했을 때의 높이가 $11 \mathrm{~cm}$ 이었다.

Table 2. Pillows used for experiment

\begin{tabular}{c|c|c|c}
\hline & Polyester sponge & Memory form & Buckwheat shell \\
\hline Type & & & \\
& & & \\
\hline Size $(\mathrm{cm})$ & $55 \times 33 \times 16(11)^{*}$ & $\begin{array}{c}53 \times 30 \times 11(5.5)^{*} \\
\{9\}^{* *}\end{array}$ & $\begin{array}{c}60 \times 40 \times 12(3)^{*} \\
\{11\}^{* *}\end{array}$ \\
\hline
\end{tabular}

※ ( )*: 가장 낮은 부분의 높이

\{\}$*$ : 머리의 평균무게 $(1.5 \mathrm{~kg})$ 로 압력을 가했을 때 높이

머리 표면에 가해지는 압력의 측정을 위해 Techstorm사 의 CPMS (clothing pressure measurement system) Ver 2.1을 사용하였고, 압력센서의 배치는 Figure 3과 같다.

근육의 신호를 추출하기 위하여 6 channels의 표면전극을 사용하였고, high gain bioamplifier, high speed videograph I/O Port가 설치된 Coulborn Instruments의 EMG (electromyography) system을 PC와 연결하여 사용하였다.

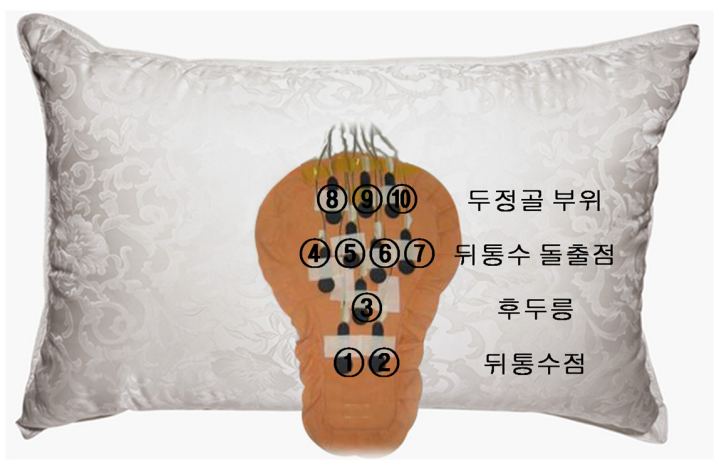

Figure 3. The locations of head pressure sensors

\subsection{Muscle selection}

베개를 베고 누울 때 머리의 폄 동작을 담당하는 왼쪽/오 른쪽 머리반가시근(left/right semispinals capitis; LSC, $\mathrm{RSC}$ )과 머리의 회전을 담당하는 왼쪽/오른쪽 목빗근(left/ right sternocleidomastoid; LSM, RSM), 옆으로 누운 경 우 머리를 지지하는 역할을 하는 왼쪽/오른쪽 등세모근(left/ right lower trapezius; LLT, RLT)으로 총 6개의 근육을 실험대상으로 하였다(Figure 4) (Kim et al., 1995).

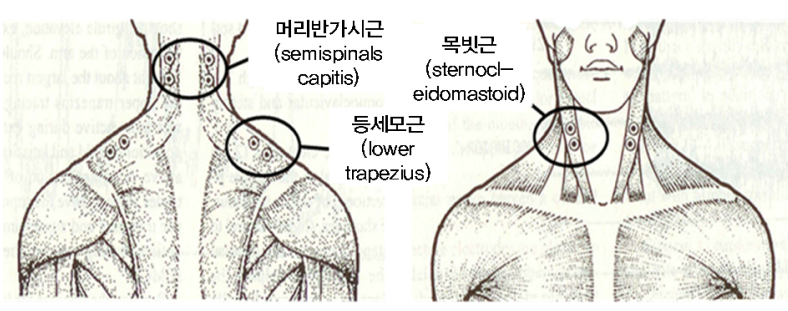

Figure 4. Muscles used in experiment ors

\subsection{Data analysis}

경추 안정도 분석을 위하여 바로 누운 자세에서는 실험참 가자의 귀구슬점과 어깨 가쪽점과 연결되는 선분과 기준선 과의 각도 $(\theta 1)$ 를 측정하고, 옆으로 누운 자세에서는 뒤통 수점과 목뒤점과의 연결되는 선과 기준선과의 각도 $(\theta 2)$ 를 측정하여 분석하였다(Figure 2).

체압분포의 분석방법은 10 개의 센서에서 측정된 압력을 Equation 3에 의해서 평균압력을 계산하고, Equation 4에 의해서 최대압력을 계산하여 분석하였다.

평균압력(avera ge pressure) $=\frac{\sum_{1}^{10} P_{i}}{10} \quad \cdots \cdots . .$. Equation 3.

최대압력(peak pressure) $=\operatorname{Max}\left(P_{1}, \cdots, P_{10}\right) \cdots$ Equation 4 .

EMG system에 수집된 데이터를 분석하기 위하여 Windaq software를 사용하였다. 베개의 재질과 형태에 따른 근육의 활동도와 피로도를 분석하기 위하여 10 초 동안 수집된 데이 터 중, 앞의 4 초와 뒤의 3 초의 데이터를 제거하고, 3 초 동안 의 데이터를 사용하였다. 정규화된 $\mathrm{MPF}$ 값을 분석하기 위 하여 1024-point 퓨리에 변환(fast fourier transform)을 실시하였다. 작업빈도와 회복시간에 따른 각 작업별 $\mathrm{MPF}$ 값을 분석하기 위하여 초기의 $\mathrm{MPF}$ 값을 기준으로 정규 화(normalization) 하였다. RMS와 정규화된 $\mathrm{MPF}$ 값들은 $\mathrm{SAS}$ 통계 패키지를 사용하여 베개의 종류와 자세에 따른 
분산분석을 실시하였다.

정규화된 $\mathrm{MPF}$ 값을 구하는 방법은 Equation 5와 같다 (Lee at al., 2006).

Normalized MPF $=\frac{\text { 매회 측정된 MPF 평균 }}{\text { 초기 실행시 얻어진 MPF 평균 }} \cdots$ Equation 5.

\section{Results}

\subsection{Deviated neck angle}

베개의 중요한 기능은 서 있을 때의 목 자세와 각도를 누 운 상태에서도 자연스럽게 유지하도록 해주어야 한다는 것 이다. 이러한 이유는 목각도가 서있는 경우와 유사한 조건일 경우 역학적으로 유리하기 때문이다. 경추의 디스크(disc) 에 부과되는 압축력은 경추가 서있는 경우(erect stance)에 compressive load가 상대적으로 작다고 한다(Levangie and Norkin, 2005). 경추(spine)가 서있는(erect) 경우 자 연스럽게 형성되는 만곡 각도에서 경추 디스크에 가해지는 압축력(compression force)이 고르게 분포되어 디스크에 가해지는 압력(pressure; 단위 면적당 압축력)이 가장 작기 때문이다. 그러므로, 누운 자세에서도 경추의 만곡 각도가 유지될 경우 디스크에 대한 부담이 가장 적다고 볼 수 있다. 이러한 원리는 허리에서도 유사하게 적용된다.

따라서, 본 연구에서는 서있는 자세를 기준으로 세 가 지 베개를 베고 누있을 때의 목각도 변화량을 측정하였다 (Table 3).

바로 누운 경우 세 가지 베개 모두 목각도 변화량이 $15^{\circ}$ 이상임을 알 수 있다. 그러나 옆으로 누운 경우 목각도 변화 량이 바로 누운 경우보다 작음을 관찰할 수 있었다. 바로 누 운 경우는 메모리폼 베개의 목각도 변화량이 비교적 작았으 며, 옆으로 누운 경우는 메밀 베개의 목각도 변화량이 작은 것으로 나타났다.

Table 3. The amount of neck angle deviation with various pillows (unit: degree)

\begin{tabular}{l|c|c|c}
\hline Posture & $\begin{array}{c}\text { Polyester } \\
\text { sponge }\end{array}$ & $\begin{array}{c}\text { Memory } \\
\text { form }\end{array}$ & $\begin{array}{c}\text { Buckwheat } \\
\text { shell }\end{array}$ \\
\hline Supine position $^{\mathrm{a}}$ & 21.143 & 16.714 & 17.857 \\
\hline Lying down to side $^{\mathrm{b}}$ & -5.715 & -8.286 & 0.143 \\
\hline
\end{tabular}

Negative value: flexion posture

Positive value : extension posture

a. Supine posture(tragion-shoulder tip point)

b. Lying down to side(inion-back neck point)

\subsection{Head pressure}

바로 누운 경우 머리 표면의 평균압력(average pressure) 은 폴리에스테르 쿠션 베개가 $20.76 \pm 5.27 \mathrm{~g} / \mathrm{cm}^{2}$, 메모리 폼 베개가 $15.89 \pm 9.86 \mathrm{~g} / \mathrm{cm}^{2}$, 메밀 베개가 $16.88 \pm 6.38$ $\mathrm{g} / \mathrm{cm}^{2}$ 으로 나타났다. 최대압력 (peak pressure)은 폴리에 스테르 쿠션 베개가 $26.68 \mathrm{~g} / \mathrm{cm}^{2}$, 메모리폼 베개가 30.04 $\mathrm{g} / \mathrm{cm}^{2}$, 메밀소재 베개가 $21.98 \mathrm{~g} / \mathrm{cm}^{2}$ 로 나타났다. 평균압력 은 메모리폼 베개가 가장 낮았으나 최대압력은 메밀 베개가 낮게 나타났다. 이러한 결과는 메밀 베개가 머리 부위의 압 력을 비교적 고르게 분산시켜 주는 것으로 판단할 수 있다.

세 가지 베개 모두 뒤통수점과 뒤통수 돌출점에 압력이 집중된다는 사실을 관찰할 수 있었다. 그러나 메모리폼 베개 의 경우 그 형태의 특성상 뒤통수점 1,2 의 압력이 뒤통수 돌출점에서의 압력보다 상대적으로 높은 것을 확인할 수 있 다. 또한, 후두부의 함몰 부위인 후두릉 (occipital crest) 3 과 옆머리점 가상 평행선을 기준으로 뒤통수 돌출점 4 번과 두정골 (parietal bone)에 해당하는 두정골 8번, 9번, 10번 센서에서는 후두부의 형태(Shin et al., 1998) 때문에 3가 지 베개 모두 압력이 실리지 않음을 알 수 있었다. 따라서, Figure 5에서 압력이 실리지 않은 센서에 대한 값은 결과에 서 표현하지 않았다. 이러한 결과는 후두부의 뒤통수점에 해 당하는 외후두부 융기 (external occipital protuberance)를 기준으로 위쪽과 아래쪽에 위치한 센서들의 압력이 가해지 지 않은 결과로 볼 수 있다.

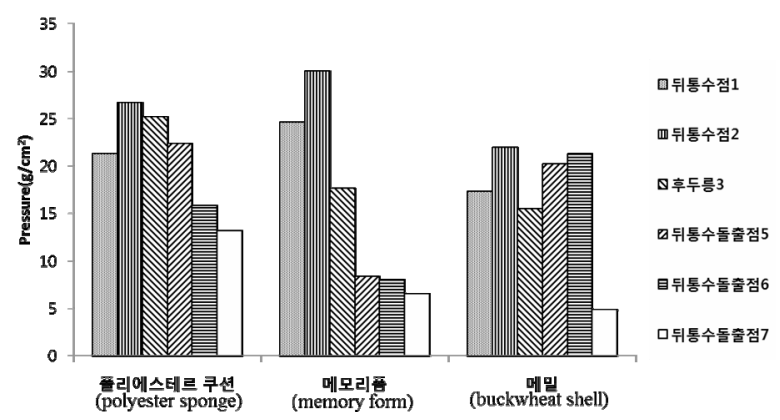

Figure 5. Distribution of head pressure in different pillows (supine posture)

옆으로 누운 경우 평균압력은 폴리에스테르 쿠션 베개가 $7.49 \pm 6.81 \mathrm{~g} / \mathrm{cm}^{2}$, 메모리폼 베개가 $9.38 \pm 7.41 \mathrm{~g} / \mathrm{cm}^{2}$, 메 밀 베개가 $8.42 \pm 6.44 \mathrm{~g} / \mathrm{cm}^{2}$ 로 나타났다. 최대압력은 폴리 에스테르 쿠션 베개가 $17.92 \mathrm{~g} / \mathrm{cm}^{2}$, 메모리폼 베개가 22.39 $\mathrm{g} / \mathrm{cm}^{2}$, 메밀 베개가 $16.20 \mathrm{~g} / \mathrm{cm}^{2}$ 로 나타났다. 평균압력은 폴리에스테르 쿠션 베개가 가장 낮게 나타났으나, 최대압력 은 메밀 베개가 가장 낮게 나타났다(Figure 6). 


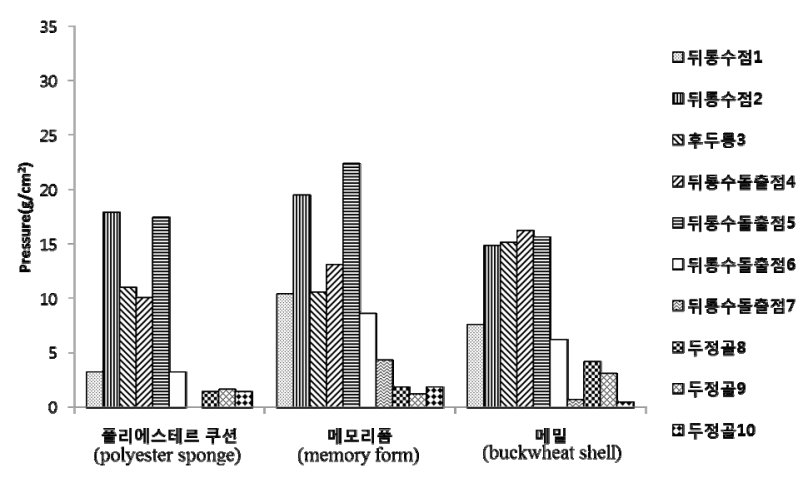

Figure 6. Distribution of head pressure in different pillows (lying down to side)

베개의 종류에 따른 머리 표면의 체압분포에 대하여 요인 별 분산분석을 실시하였다(Table 4 ). 분석결과 머리 표면의 위치에 따른 압력이 유의한 $(\alpha=0.05)$ 차이를 보이는 것으 로 나타났다. 하지만, 자세와 베개의 종류 각각에 대해서는 차이가 없는 것으로 나타났다.

머리 표면의 부위별 압력과 자세는 유의미한 관계가 있어, 머리 부위의 압력이 수면 자세에 의하여 영향을 받는다고 할 수 있다.

Table 4. ANOVA result of head pressure affected by posture and pillow material

\begin{tabular}{c|r|r|r|c|c}
\hline Source & \multicolumn{1}{c|}{ df } & \multicolumn{1}{c|}{ SS } & \multicolumn{1}{c|}{ MS } & F value & Pr $>\mathrm{F}$ \\
\hline $\begin{array}{c}\text { Pressure location } \\
\text { (sensor location) }\end{array}$ & 9 & 3240.238 & 360.026 & 4.212 & $0.027^{* *}$ \\
\hline Posture & 1 & 95.602 & 95.602 & 0.812 & 0.394 \\
\hline Pillow material & 2 & 1.069 & 0.534 & 0.014 & 0.986 \\
\hline $\begin{array}{c}\text { Pressure location } \\
(\text { sensor location) } \\
\times \text { Posture }\end{array}$ & 9 & 807.064 & 89.674 & 6.866 & $0.001^{* *}$ \\
\hline $\begin{array}{c}\text { Pressure location } \times \\
\text { Pillow material }\end{array}$ & 18 & 159.482 & 8.860 & 0.678 & 0.791 \\
\hline $\begin{array}{c}\text { Posture } \\
\times \text { Pillow material }\end{array}$ & 2 & 82.307 & 41.153 & 3.151 & $0.067^{*}$ \\
\hline${ }^{* *} p<0.05,{ }^{*} p<0.1$ \\
$p<$
\end{tabular}

\subsection{Muscle activity}

베개별 근육활동도 측정결과는 바로 누운 자세에서 차이 를 보이지 않는 것으로 나타났다(Figure 7). 옆으로 누운 자 세에서는 메모리폼이 근육활동도가 다소 높고, 메밀소재 베 개의 근육활동도가 낮은 경향성을 보이지만 통계적으로 유 의한 차이는 나타나지 않았다(Figure 8).

베개의 종류에 따른 근육의 활동도(RMS) 값의 요인별 분

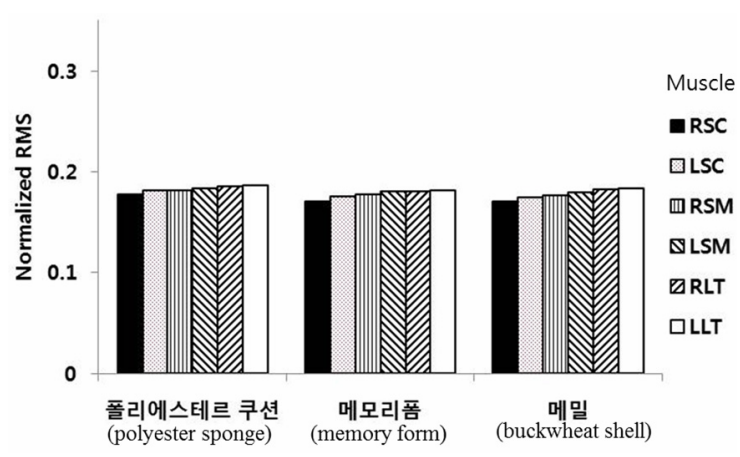

Figure 7. Distribution of RMS in different pillows (supine posture)

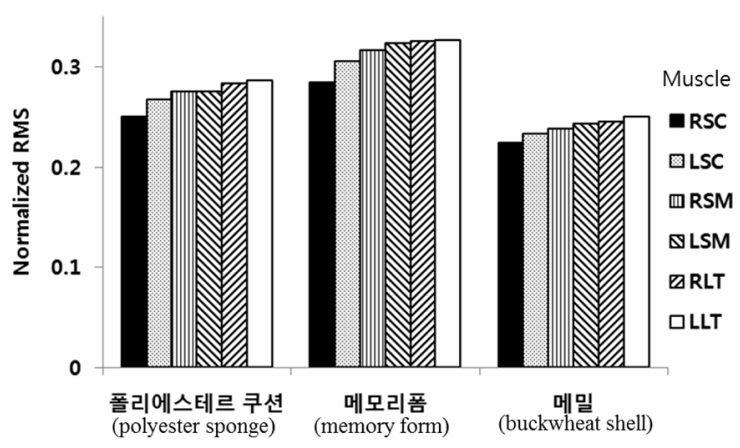

Figure 8. Distribution of RMS in different pillows (lying down to side)

산분석을 하였다(Table 5). 분석결과 자세에 따른 근육활동 도는 유의수준 $\alpha=0.1$ 에서 차이가 있는 것으로 나타났다. 하지만, 베개에 따른 근육활동도 값은 유의수준 $\alpha=0.1$ 에서 유의한 차이를 보이지 않았다 $(p=0.426)$. 이는 통계적으로 바로 누워 있는 경우 베개의 종류는 근육의 사용량에 영향을 미치지 않지만, 옆으로 눕는 자세의 경우는 근육의 사용량에 영향을 미친다는 것을 의미한다.

베개의 종류에 따른 자세별 근육사용량의 차이는 유의수 준 $\alpha=0.05$ 일 때, 통계적으로 유의미한 차이를 나타내지 않 았다 $(p=0.383)$. 이는 특정 베개가 다른 베개에 비해 자세 가 변화될 때 근육의 이완효과를 유발시키지 않는다는 것을 보여준다. 그러나 본 실험에서는 초기사용(10초간) 시점만 을 측정하였으므로, 미세한 근육활동의 차이가 장시간 베개 를 사용하였을 때에는 유의미한 결과가 도출될 수 있는 가능 성을 배제할 수 없다. 자세에 따른 근육의 사용량은 유의수 준 $\alpha=0.1$ 에서 차이가 있는 것으로 나타났으며, 베개별 근 육사용량도 차이가 있는 것으로 나타났다. 이러한 결과는 Figure 7 에서 바로 누운 경우의 베개별 근육사용량은 차이 가 없지만, Figure 8에서 옆으로 누운 경우 베개별 근육사용 량의 차이 때문으로 볼 수 있다. 
Table 5. ANOVA result of muscle activity affected by posture, pillow material and muscle selection

\begin{tabular}{l|r|c|c|c|c}
\hline Source & df & SS & MS & F & Pr $>$ F \\
\hline Posture & 1 & 0.022 & 0.023 & 3.87 & $0.097^{*}$ \\
\hline Pillow & 2 & 0.002 & 0.001 & 0.92 & 0.426 \\
\hline Muscle & 5 & 0.001 & 0.001 & 3.56 & $0.012^{* *}$ \\
\hline Posture $\times$ Pillow & 2 & 0.002 & 0.001 & 1.04 & 0.383 \\
\hline Posture $\times$ Muscle & 5 & 0.001 & 0.001 & 2.36 & $0.065^{*}$ \\
\hline Pillow $\times$ Muscle & 10 & 0.001 & 0.001 & 2.44 & $0.016^{* *}$ \\
\hline Posture $\times$ Pillow $\times$ Muscle & 10 & 0.001 & 0.001 & 1.90 & $0.062^{*}$ \\
\hline
\end{tabular}

${ }^{*} p<0.1, \stackrel{* *}{p} p<0.05$

베개별로 누운 자세와 개별근육이 근육활동도에 미치는 영향을 비교하기 위하여 주효과 분석을 실시하였다. 메밀 베개의 경우 $(p=0.973)$ 와 폴리에스테르 쿠션 베개의 경우 ( $p=0.490)$ 근육을 전체적으로 고르게 사용함을 알 수 있 다. 이는 메밀 베개와 폴리에스테르 쿠션 베개를 사용할 때 어느 특정 근육에 부하가 집중되지 않고 모든 근육을 고르 게 사용하고 있음을 의미한다. 그러나 메모리폼 베개 $(p=$ 0.032)의 경우 근육간의 부하의 차이가 있음을 알 수 있었 다. 이는 장시간 수면 자세를 유지할 경우 특정 근육의 긴장 이 유발될 수 있는 가능성이 있다고 볼 수 있다.

\subsection{Muscle fatigue}

정상적인 수면의 경우 신체 자세를 비교적 자주 변경하고, 그 움직임의 횟수는 수면시간 중 20 40 또는 60회 정도라 는 연구(Johnson, 1931)를 근거로 베개사용 지속시간을 20 분으로 가정하고 피로도 실험을 실시하였다. 베개를 사용하 기 시작한 시점의 피로도를 기준으로, 사용하고 난 후 근육 의 피로도 변화(MPF shift)를 비교하였다.

기술통계상으로는 바로 누운 경우 폴리에스테르 쿠션 베 개의 $\mathrm{MPF}$ shift 값이 가장 크게 변화하였으며, 메모리폼 베 개의 $\mathrm{MPF}$ shift 값이 모든 근육에서 가장 적게 변화한 것으 로 나타났다(Figure 9). 이러한 결과는 메모리폼 베개가 근 육의 이완을 도와주는 것으로 볼 수 있다.

반면에, 폴리에스테르 쿠션 베개를 사용하였을 경우 근육 의 긴장이나 활동이 상대적으로 많은 것을 의미하며, 장시간 수면시 자세로 인하여 국부근육에 피로를 유발할 수 있는 가능성이 높다는 것을 의미한다. 옆으로 누운 경우에는 크 게 차이가 나타나지 않았지만, 메밀 베개의 MPF shift 값의 변화가 가장 작게 나타났다(Figure 10).

근육피로도 변화에 대한 분산분석 결과 유의수준 $\alpha=$ 0.05에서 유의한 차이는 나타나지 않았다(Table 6).

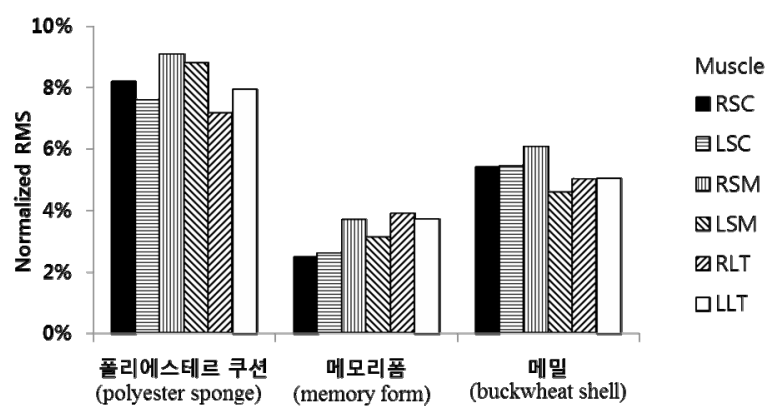

Figure 9. Distribution of MPF shift ratio in different pillows (supine posture)

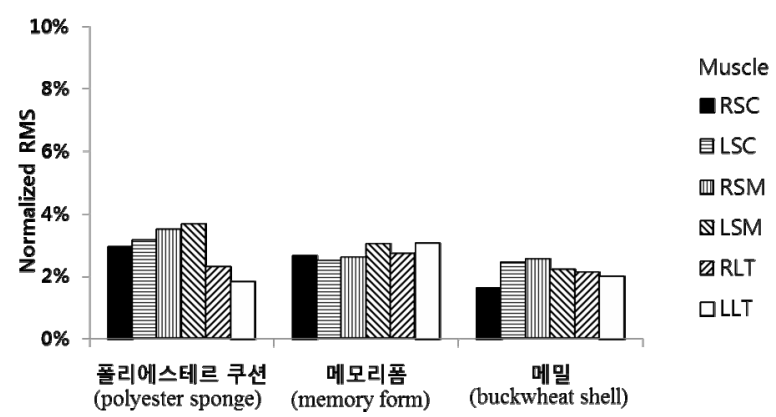

Figure 10. Distribution of MPF shift ratio in different pillows (lying down to side)

Table 6. ANOVA result of MPF affected by posture and pillow

\begin{tabular}{l|c|c|c|c|c}
\hline Source & df & SS & MS & F & Pr $>F$ \\
\hline Posture & 1 & 0.015 & 0.015 & 2.37 & 0.3666 \\
\hline Pillow & 2 & 0.008 & 0.004 & 2.11 & 0.3214 \\
\hline Posture $\times$ Pillow & 2 & 0.006 & 0.003 & 5.02 & 0.1662 \\
\hline
\end{tabular}

\section{Discussion}

본 연구에서는 베개의 종류와 자세에 따른 근육의 사용량 과 인체에 미치는 효과를 평가하였다. 베개의 속재질에 따른 수면 자세를 평가하기 위하여 폴리에스테르 쿠션 베개, 메모 리폼 베개 그리고, 메밀 베개를 사용하였고, 경추안정도, 체 압, 근육의 활동도와 피로도를 측정, 분석하였다.

Levangie and Norkin(2005)은 경추의 디스크(disc)에 부과되는 압축력 (compressive load)은 경추가 서있는 경 우(erect stance)에 상대적으로 작다고 하였다. 서있는 (erect) 경우 자연스럽게 형성되는 만곡 각도에서 경추 디 스크에 가해지는 압축력 (compressive force)이 고르게 분 포되어 디스크에 가해지는 압력 (pressure; 단위 면적당 압 
축력)이 가장 작다. 그러므로, 누운 자세에서도 경추의 만곡 각도가 유지될 경우 디스크에 가해지는 압력이 가장 작다고 예측할 수 있다. 따라서, 베개를 평가할 때, 서있을 때와 비 교하여(단, 바른 자세로 서있을 때) 목각도의 변화량이 작을 수록 디스크에 대한 부담을 줄여줄 수 있다.

한편, 근육활동도 측면에서 Table 3 의 바로 누운 경우 목 각도 변화량의 차이가 상대적으로 크지 않고, 반면에 옆으로 누운 경우 메밀 베개의 목각도 변화량이 상대적으로 작은 것을 알 수 있었다. 이 경우, Figure 8에서 통계적으로 유의 하지는 않지만 근육활동도가 다른 근육에 비해 상대적으로 낮은 것을 알 수 있었다. 그러므로, 목각도 변화량이 적은 것 과 근육사용량이 상대적으로 줄어드는 경향과의 연관성을 관찰할 수 있었다.

경추의 이상적인 만곡 각도와 비교하였을 때, 목각도 변화 량이 바로 누운 경우 세 가지 베개 모두 $16^{\circ}$ 에서 $21^{\circ}$ 사이 로 폴리에스테르 쿠션 베개가 상대적으로 높게 나타났다. 옆 으로 누운 경우 목각도 변화량은 바로 누운 경우 보다 변화 정도가 작았는데, 특히 메밀 베개의 경우 $0^{\circ}$ 에 가깝게 변화 하여 다른 두 베개보다 상대적으로 작은 것을 알 수 있었다. 이는 메밀 베개가 어깨 높이를 기준으로 머리 높이를 적절 하게 유지시켜 경추를 일직선으로 유지시켜 준다는 것을 의 미한다. Nam and Lee(1989)는 적정 베개의 높이가 남자는 바로 누운 자세에서 $8.0 \pm 0.5 \mathrm{~cm}$, 옆으로 누운 자세에서 9.0 $\pm 0.5 \mathrm{~cm}$ 가 적절하다고 하였다. 메밀 베개의 높이는 바로 누운 자세에서 $11 \mathrm{~cm}$ 로 기존연구 결과와 다소 차이가 있지 만 직립일 경우 경추의 각도와 가장 유사한 목각도를 유지 시키는 것으로 나타났다.

체압은 바로 누운 자세에서 메모리폼 베개의 평균압력이 가장 낮았으며, 최대압력의 경우 메밀 베개가 비교적 낮게 나타났다. 메모리폼 베개의 전체적인 압력의 합은 낮게 기 록되었으나, 특정 센서에 압력이 집중되는 현상을 관찰할 수 있었고, 메밀 베개는 목주변의 압력을 센서별로 분산시키는 경향이 있다는 것을 알 수 있었다. 옆으로 누운 자세에서는 평균압력과 최대압력 모두 메밀 베개가 낮은 것으로 나타 났다.

누운 자세별 비교에서는 통계적으로 유의한 차이가 발견 되지 않았으나 Figure 5와 6을 비교했을 때 기술통계상으로 폴리에스테르 쿠션 베개의 평균압력에서 자세별 차이가 가 장 크게 나타난 것을 관찰할 수 있었다. 폴리에스테르 쿠션 베개의 재질로 사용된 폴리에스테르는 바로 누운 자세에서 뒤통수 돌출부위의 체압이 다른 두 베개보다 상대적으로 높 음을 관찰할 수 있었다.

근육의 활동도 분석결과 메모리폼 베개의 경우 자세와 근 육에 따라 근육의 활동도가 달라진다는 것을 보여주었다. 이 는 어떤 수면 자세를 갖느냐에 따라 메모리폼 베개가 근육
이완 효과가 달라질 수 있다는 가설을 갖게 한다. 메모리폼 베개의 근육피로도가 바로 누운 자세에서 상대적으로 적으 나 옆으로 누운 자세에서는 다른 베개와 큰 차이를 보이지 않는 것을 보면(Figure 9,10 ), 이러한 가설의 타당성을 짐 작할 수 있다.

근육피로도는 바로 누운 경우에는 메모리폼 베개가, 옆으 로 누운 경우에는 메밀 베개가 상대적으로 적은 것으로 측정 되었다. 폴리에스테르 쿠션 베개는 바로 누웠을 때의 피로도 가 다른 베개에 비해 상대적으로 높게 기록되었다. 그러나 이러한 차이는 통계적으로 유의하지 않은 것으로 나타났고, 그 이유는 피로도를 20 분 동안 고정된 자세로부터 추출한 실험적 한계 때문이라고 추측할 수 있다.

본 연구결과를 바탕으로 볼 때, 베개의 속재질이 형태나 높이와 같이 인체공학적인 베개를 구성하는 중요한 요인이 될 수 있음을 알 수 있었다. 체압측정 결과는 머리와 목의 접촉 부위와 자세에 따라 접촉압력의 크기의 차이가 커 이를 설계에 고려하는 것이 필요하다고 판단되었다. 근전도의 변 화는 주어진 실험상황이 충분한 피로를 유발시키지 못한 면 이 있어 통계적 의미를 찾기 어려웠으나, 그 반면 현저한 경 향성을 보여주어 장시간 베개 사용시 발생할 수 있는 근육피 로도를 예측할 수 있는 간접적 자료를 제공하였다. 이는 메 모리폼 베개와 더불어 메밀소재 베개가 목 디스크의 예방과 관리에 사용될 수 있는 가능성을 보여주었다.

\section{Conclusion}

본 연구에서는 베개의 속재질에 따른 경추의 안정도, 머리 부위의 체압과 목, 어깨 부위의 근육사용량이 인체에 미치 는 효과에 대하여 폴리에스테르 쿠션 베게, 메모리폼 베개, 메밀 베개를 대상으로 생체역학적인 방법을 이용하여 정량 적으로 비교하였다.

연구결과 베개의 속재질은 수면 자세에 따라 민감한 생체 역학적 특성을 보여주었다. 그러므로, 선호하는 수면 자세에 따라 개인에게 적합한 베개의 속재질이 선택되어야 인체공 학적인 베개로서의 기능을 완성할 수 있을 것으로 예상된다. 본 연구의 결과는 베개의 높이, 형태와 더불어 인체공학적 베개설계에 필요한 자료로 활용될 수 있을 것이다.

\section{References}

Cyriax, J., Textbook of Orthopedic Medicine; $8^{\text {th }}$ ed., Bailliere Tindall, 
London, 1988.

Hur, J. G. and Yang, Y. A., The Effect of Ergonomic Pillow in Patient with Chronic Neck Pain, Journal of the Ergonomics Society of Korea, 25(1), 17-25, 2006.

Kim, K. Y., Kim, W. K., Kim, J. D., Kim, J. S., Park, C. H., Lee, H. S., Choi, Y. J. and Han, D. S., Human Anthropometry, Jungmoon, 1995.

Kim, J. Y., Park, J. S., Yoo, S. W., Lee, S. J. and Ko, T. S., "Ergonomic Evaluation of "Air-Ball" Mattress by using Skin Pressure and Temperature Changes", Proceeding of Ergonomics Society of Korea, Autum, 290-294, 2007.

Kwon, B. A., Lee, Y. C. and Hur, J. G., A New Design of Cervical Pillow, Journal of Korea Society of Safety Education, 2(2), 5-21, 1998.

Kwon, K. S., Kim, J. S. and Park, S. J., Recognizing Sleeping Posture on Bed by using the Measurement of Body Pressure Distribution, Journal of the Society of Korea Industrial and Systems Engineering, 22(52), 211-219, 1999.

Lee, T. Y., Kim, J. Y. and Shin, H. J., Analysis of Trunk Muscle Fatigue as the Frequency of Lifting/Lowering and Recovery Time Change, Journal of the Ergonomics Society of Korea, 25(2), 197-204, 2006.

Levangie, P. K. and Norkin C. C., Joint Structure and Function - A Comprehensive Analysis, $4^{\text {th }}$ ed., F. A. Davis Company, Philadelphia, 2005.

Liebenson, C., Rehabilitation of The Spine; $1^{\text {st }}$ ed., Williams and Wilkins, 1996.

Nam, Y. J. and Lee, Y. S., The Ergonomic Study on the Height of the Pillow [II], Journal of the Ergonomics Society of Korea, 8(1), 3-17, 1989.

Park, J. S. and Kim, J. Y. "Physical strength and fatigue measurement of the shoulder in a sitting position", The Japanese Journal of Ergonomics, 44, 386-388, June, 2008.

Robert, A. L., Marco, P. and Keith, V. K., Cervical Pain: A Comparison of Three Pillows, The American Academy of Physical Medicine and Rehabiitationl, 78, 193-198, 1997.

Shin, M. K., Koo J. Y., Kim, B, W., Shim, J. W., Yoo, K. W. and Cho, K. P., Human Anatomy, Hynmoon, Seoul, 1993.

\section{Author listings}

Jung Yong Kim: jungkim@hanyang.ac.kr

Highest degree: Ph.D., Department of Industrial Engineering, The OHIO state University

Position title: Professor, Department of Industrial and Management Engineering, Hanyang University

Areas of interest: Biomechanics, Psychophysiology, PUI design

Ji Soo Park: jspark21@hanyang.ac.kr

Highest degree: M.S., Department of Industrial Engineering, Kyonggi University

Position title: Doctoral candidate, Department of Industrial and Management Engineering, Hanyang University

Areas of interest: Biomechanics, Psychophysiology, Bio-signal processing, PUI design

Dae Eun Park: depark@daum.net

Highest degree: M.S., Department of Industrial Engineering, Hanyang University

Position title: Assistant manager, Korea Industrial Safety Association Areas of interest: Biomechanics, Safety engineering

Date Received : 2010-04-13

Date Revised :2011-02-25

Date Accepted : 2011-03-01 